\title{
The failure of the Šik's reform in Czechoslovakia in the 1960s
}

\section{Tomáš NIKODYM}

\author{
Katedra hospodářských dějin, \\ Národohospodářská fakulta, Vysoká škola ekonomická \\ Department of Economic History, \\ Faculty of Economics, University of Economics, \\ Winston Churchill Sq. 4, 13067 Praha, Czech Republic \\ nikodym.tomas@gmail.com
}

The sixties in socialist Czechoslovakia are commonly interpreted as a liberalization process in the civic, social, political and economic life. It was clear that the soviet type of central planning did not fulfill the promised vision of a classless prosperous society. After the failure of Rozsypal's reform in 1962, there was a new chance to reform the collapsing economic system - the so called Šik's reform.

The main "radical" idea of the reform was to unite the central plan and the market. In order to realize it, it was necessary to reconsider the status of enterprises in the economy and the importance of the price system. What remained unchanged was the opinion on private property - there was no proposal to change property relations. The most common interpretation of Šik's reform is that it meant a real change in the socialist economy. A military intervention in August 1968 was considered to make the end of the reform. I want to offer a new perspective. Of course, it is very difficult to evaluate the results of the reform as it was not put into practice completely and there was only little time to see real effects. How is it possible to handle the absence of relevant data? In an alternative point of view the reform can be seen as an issue for economic theory. By using the theory, we are able to answer the question about the functionality of the roots of reform. It would be a mistake to take the theoretical basis of the reform as functional without other analysis. If the historical documents claim, there were market and price system, it does not mean it is necessarily true. By considering the economic theory the general question is different. It is not about when the reform ended but - whether it could work?'

I will now analyze some basic documents and theoretical works of the authors of the reform. I will also compare the results of my analysis with the real reform effects.

\section{The price mechanism}

The very first complex reform proposal was introduced on 18 March 1964 after a two-year discussion about the form and meaning of the reform. In the document called "The Principles of New Planning System" the most pressing problems of socialist economy were identified - resource depletion caused by extensive production method and bureaucrat-

1 Read more about the relation of economic theory and history in Ludwig von MISES, Theory and History, Auburn 2007; Ludwig von MISES, Human Action, Auburn 1998, 30-64; Murray N. ROTHBARD, Praxeology: The Methodology of Austrian Economics, URL: http://mises.org/rothbard/praxeology.pdf (visited: August 2013). 
ic-administrative management. ${ }^{2}$ The goal for the new system - based on plan but also using market relations, such as prices, entrepreneurship and "material incentives" 3 - was to overcome these difficulties.

The typical characteristic features of a socialist economy are fixed prices set by the central authority. It had to be changed. The price was newly regarded as a tool of consumer pressure on producers. It is possible to overcome the existing gap between supply and demand only if the prices are flexible. "We have to overcome dogmatic vision of fixed prices in socialism" wrote Šik. ${ }^{4}$ The aim was to create a price mechanism with three kinds of prices - fixed, limited and flexible. ${ }^{5}$ Fixed price was determined for raw materials or energy due to mass consumption. Limited price meant, there was a specified zone, where the price could change freely. This kind was typical for industrial products. Flexible price was set for the remaining goods. Now, the conclusion of some historians is that most prices were set on market. ${ }^{6}$ This statement is too hasty. What does "flexible price" really mean?

The further study shows, that flexibility of both - limited and flexible price - meant only a drop in prices. ${ }^{7}$ To change limited price was also possible only at a certain date. Now, the most important question is why they were so scared of price growth. They supposed that the interests of producers are random and there is no order in the economy. Flexible prices follow these selfish interests and disorder. Firstly, it is important to realize that the interests of producers in market economy are not random - they are reactions to consumer demand. Those who want to prosper must serve the consumers. Although the production on the market might look anarchic and random, the opposite is true. Using the price system production is aimed to satisfy the most urgent needs. If the price does not change, it loses its meaning. This applies both to growth and decline in prices. The price as information about scarcity makes sense only in case it corresponds to the situation on the market. If not, there are some negative effects. A regulated price below market price leads to the shortage of goods when the demand exceeds the supply. Not only does this mean long queues in front of stores (the typical picture of a socialist economy), but also the creation of the black market. The price regulated above market price creates unsold surplus. High price is attractive for other producers who want to join the regulated sector of the economy. On the other hand, the consumer demand is discouraged. As Rothbard wrote: "Entrepreneurs operate on the basis of certain criteria: prices, interest rates, etc., established by the free market. Interventionary tampering with these criteria destroys the adjustment and brings about losses as well misallocation of resources in satisfying consumer wants. ${ }^{18}$

2 Národní archiv Praha (National archive in Prague; hereinafter referred only as NA), fund (f.) 10/4, vol. 13, doc. no. 32, b. 1, Zásady nové soustavy plánovitého ř́zení národního hospodářství (The Principles of New Planning System), 18. 3. 1964, submitted by Ota Šik and František Vlasák.

3 At the very beginning they did not use the phrase "market system", because market is typical for capitalist economies. The market was called "commodity-money relations".

4 Problém zdokonalení soustavy plánovitého řizení (The Problem of Improving the Planning System), Rudé právo, 1963, Year 44, No. 322, 22 November.

5 NA, f. 10/4, vol. 13, doc. no. 32, b. 1, 56-60.

6 Ivan JAKUBEC et al, Hospodářský vývoj českých zemí v období 1848-1992, Praha 2008, 211.

7 NA, f. 10/4, vol. 13, doc. no. 32, b. 1, 55; Ota ŠIK, K problematice socialistických zbožních vztahů, Praha 1964, 283; Ota ŠIK, Plán a trh za socialismu, Praha 1967, 190.

8 Murray N. ROTHBARD, Man, Economy and State with Power and Market, Auburn 2009, 1078. 
If there was a pressure on price rise, the producer would be obliged to expand production from its own reserves. This should get the demand and supply back into equilibrium at the original price. The only possible case to increase the price, was to demonstrate objective reasons why it is impossible for the enterprise to expand production. ${ }^{9}$ In other words, the idea was to skip market adaptation to new conditions and reach the equilibrium immediately. The result of this intervention is setting a price below the market level. The lower price leads to an increase in consumer demand which strengthens again the pressure on price rise. The producer would run out of reserves very soon and the price will increase due to "objective conditions". How would the situation look like in case of fully flexible prices? The higher price would attract new producers and investments into this sector of economy which will increase production. The increase in production will cause a pressure on the decline in prices and the economy would reach a new equilibrium. It wouldn't happen without a price rise because producers and investors wouldn't see the information (in the form of price) about new profit opportunities. "We must look at the price system as such a mechanism for communicating information if we want to understand its real function - a function which, of course, it fulfills less perfectly as prices grow more rigid... The most significant fact about this system is the economy knowledge with which it operates, or how little the individual participants need to know in order to be able to take the right action." 10 So in case of rigid prices information is "only" distorted. On the other hand, when the enterprises have to produce from reserves, the information do not occur. A possible way to make enterprises produce from reserves was to confiscate "speculative profits" by the central and supervisory authorities. That could happen, if the enterprises underestimated their production possibilities. ${ }^{11}$ What is also important, there was no clear border what was considered to be speculative profit and what not. That brought another uncertainty into the economic system. The uncertainty dampens entrepreneurial activities. The regulation also does not motivate the producers to create reserves. Thus, it is better for a producer to spend the profit earlier than it is recognized as speculative.

Another problem to the price construction is caused by the marxist approach. Šik and other reform authors assumed, the basis of price is "the value" - inevitable long-term trend. The value is just another word for socialist production price which means the cost of production and labour. So, there can be a clash between "the value" and the market price as a "utility value" in short run. ${ }^{12}$ In real price system the price construction is reversed. ${ }^{13}$ All prices are based on the consumers' subjective valuation. "Prices are the outcome of valuation preferring a to b. They are social phenomena as they are brought about by the interplay of the valuations of all individuals participating in the operation of market." ${ }^{14}$ What about 9 ŠIK, 1964, 190; ŠIK, 1967, 283.

10 Friedrich August von HAYEK, The Use of Knowledge in Society, 1945, 526-527, URL: http://www.jstor.org/ stable/1809376 (visited: August 2013).

11 ŠIK, 1964, 192; ŠIK, 1967, 287.

12 ŠIK, 1967, 287-288.

13 Robert MURPHY, Problems with the Cost Theory of Value, URL: http://mises.org/daily/5297/Problems-withthe-Cost-Theory-of-Value (visited: August 2013); Robert MURPHY, The Labor Theory of Value: A Critique of Carson's Studies in Mutualist Political Economy, URL: http://mises.org/journals/jls/20_1/20_1_3.pdf (visited: August 2013); Carl MENGER, Principles of Economics, 2007, 114-174; MISES, 1998, 324-354.

14 MISES, 1998, 328. 
the prices of the factors of production? These prices also depend on the consumers' subjective valuation, but in this case only indirectly. "The prices of the goods of higher orders are ultimately determined by the prices of the goods of the first or lowest order, that is, the consumers' goods." ${ }^{15}$ Due to the same market process, similarly to the consumer goods, the resources are directed to the most urgent use. The question is why the reform authors were still under the influence of the cost theory of value. ${ }^{16}$ In my opinion, it is due to the absence of private property in the reform proposal. In case of socialized ownership, there is no market of the factors of production, so no prices are determined by the market of consumer goods. What does it mean for the economy?

It is clear, that in capitalist economy based on property rights, the economic structure is organized rationally by market process with price mechanism. So, the mission for a socialist planner is how to organize the economy without price mechanism and ownership of the factors of production. The simplest way to show the differences between the organization of production in capitalist and socialist economy is to set an example. Imagine, there is a mountain between two cities and the goal is to build a road between these cities. The first possibility is to build a tunnel through the mountain, the second is to build it around the mountain. Which would you choose? In the system based on property rights it is not hard to calculate the cost of each possibility and to choose the best variant. This calculation is possible only due to the existence of the market of factors of production and their prices. The socialist planner does not have these instruments of economic calculation. It was a mistake to accuse capitalism of anarchic organization of production, the opposite is true. "Socialist economy is an oxymoron because economy means rational resource allocation." 17 Now it is clear, the "price mechanism" was very rigid. The title of prices - flexible and limited did not correspond with reality. Price mechanism makes sense only if there is free movement of prices. The necessary condition is also private ownership of production factor. In the opposite case there is no market and prices.

\section{The status of the enterprise and the planning system}

Another important part of Šik's reform was the change of the status of enterprise in the economy and the planning system. The plan was to give more autonomy to the enterprises and to limit the number of directive regulations of the central office.

First, needless to say, the basic economic tool to achieve the optimal economic development was still the plan. The change was that the plan should be created by scientists, not by the subjective and ideological decisions of a central planner. The task for the scientists was to analyze the production possibilities of the economy, to predict the future development of needs and then to choose the most effective technical tools. It was also important

15 MISES, 1998, 330.

16 The cost theory of value was overcome during the so called Margninal revolution in 1870s.

17 Peter BOETTKE - Peter LEESON: Liberalism, Socialism, and Robust Political Economy, 108-109, URL: http:// papers.ssrn.com/sol3/papers.cfm?abstract_id=869124 (visited: August 2013). Read more about economic calculation in socialism in Ludwig von MISES, Economic Calculation In The Socialist Commonwealth, URL: http://mises. org/pdf/econcalc.pdf (visited: August 2013). 
to observe the development in the capitalist industrial countries. ${ }^{18}$ As Mises pointed out, the only way to improve the efficiency of socialist economy was often realized by following the development of capitalist countries. ${ }^{19}$ The question is how to predict future development of needs. In capitalist economy it is simple due to the existence of price mechanism. The rise or drop in prices inform the entrepreneurs about the needs and by following these signals the structure of economy changes. This tool is missing in socialism so the plan was based on the analysis of past development of needs using the latest computer technology and mathematical methods. ${ }^{20}$ The problem is that consumer preferences are not constant. They are changing from time to time so the success of the plan is purely coincidental. ${ }^{21}$ Limiting the number of directive regulations of the central office also meant a change of its position in economy. It does not mean that the activity of the central office was cancelled. The plan should have been based on the proposals of every single enterprise and then "harmonized" with the social plan. To harmonize all the plans and to control their "social interest" were the goals of the central office. The material incentives played an important role in the new planning system. The income of an enterprise and its employees should have depended on the real sale of goods. This motivation system depended on price mechanism reform..$^{22}$ Another reason for the continuous existence of the central office was the "blindness" of socialist enterprise. Šik was right when he mentioned: "The enterprises cannot recognize the demand of their goods and required growth of production; socialized factors of production which they can use or available workforce and the wage trends." ${ }^{23} \mathrm{On}$ the other hand, he was wrong when he thought that the central office is in a better position. Of course, the central office has statistics about the workforce or the factors of production, but it does not mean it has information about the best allocation of these resources.

It is also important to explain the difference between capitalist profit and socialist gross income which was another part of the motivation system. For Šik, as a socialist theorist, the profit maximization was unacceptable because profit contained stolen surplus value. On the other hand, gross income contained the gross profit and "the new value" - used labor. ${ }^{24}$ This "accounting trick" was designed to prevent increasing profits at the expense of wages. "The old value" which contained used material and factors of production, was not part of the gross income. It was due to misunderstanding of price construction and the cost value theory. If the basis of price was the value, the enterprise would be motivated to waste the material.

18 NA, f. 10/4, vol. 13, doc. no. 32, b. 1, 7, 19

19 Ludwig von MISES, Socialism: An Economic and Sociological Analysis, Indianapolis 1981, 118. Refer also ROTHBARD, 2009, 1272-1276; Martin MYANT, The Czechoslovak economy 1948-1988: The battle for economic reform, Cambridge 1989, 117.

20 NA, f. 10/4, vol. 13, doc. no. 32, b. 1, 23-24.

21 The concept of constant preferences is very popular in economic theory, but it does not mean it is valid in reality. There are also other ways to overcome this concept in economic theory. Refer to ROTHBARD, Toward a Reconstruction of Utility and Welfare Economics, URL: http://mises.org/rothbard/toward.pdf (visited: August 2013).

$22 \mathrm{NA}$, f. 10/4, vol. 13, doc. no. 32, b. 1, 14 .

23 ŠIK, 1968, 121.

24 ŠIK, 1968, 177. 


\section{First realization of the Šik's reform}

The official version of the reform program was approved in January 1965. The Central committee of the Communist party decided to put the reform into a practice from 1 January 1966. ${ }^{25}$ Work schedule was approved in March 1965 and the implementation was supposed to be finished in 1968. A little bit earlier few experiments took place in the most effective enterprises. The goal was to show the importance of the reform to the public. ${ }^{26}$ In his memoirs, Šik admitted the failure of these experiments. It was impossible for the enterprises to behave like a "real entrepreneurs" in the system of unchanged bureaucratic-administrative management, old directive price system or the monopoly structure of the economy. ${ }^{27}$

Another step of the reform was limiting the central plan. There was 1,338 directive tasks in 1964, 1,122 tasks in 1965 and the number decreased up to 48 in 1966. The enterprises also reached more autonomy concerning supplier-customer relationship, but the price mechanism still did not work. ${ }^{28}$ First results of reform were not positive. The power of central office was really restricted, but the officials have moved to the lower level of management. Also "the market" did not work, due to the monopoly structure of the economy. It led to the speculative behaviour of the enterprises. The fact, that socialist economy is by its nature monopolist, was underestimated. There was a consensus that it was necessary to speed up the reform and to implement the price mechanism immediately.

In March 1966 the "Program of immediate implementation of the new planning system" was presented. ${ }^{29}$ The price mechanism has been decided to reform one year earlier on 1 January 1967, improve antimonopoly regulations and modify the nature of the plan. It does not mean that the theoretical discussion has stopped. Continued discussion emphasized the position and role of enterprises in the socialist economy.

Despite the argumentation based on market relations and competition, the role of plan remained crucial for the economic development. It was supposed to be a plan that represents the goals of society and also determines the ways and means how to fulfill these goals. It was also a task for the plan to improve the market! ${ }^{30}$ In this situation when the plan was the basis of the economic system, the reform of enterprise status could never overcome the bureaucratic management. The "socialist entrepreneur" was marked as autonomous, but further study of submitted documents has showed that the personal initiative was strictly limited. The trend of the economy was designated by the central office and the "entrepre-

25 Usnesení ústředního výboru KSČ o hlavních směrech zdokonalení plánovitého řízení národního hospodářství, in Ekonomická reforma 1965-1969, Jitka VONDROVÁ (ed.), Brno 2010, 25-35.

26 Karel KAPLAN, Kořeny československé reformy 1968 I, Brno 2000, 290-291; MYANT, $1989,123$.

27 ŠIK, Jarní probuzení - iluze a skutečnost, Praha 1990, 129.

28 Zdislav ŠULC, Stručné dějiny ekonomických reforem v Československu (České republice) 1945-1995, Brno 1998a, 48; NA, f. 10/4, vol. 7, doc. No. 15, b. 2, Soubor návrhů k provádění cenové politiky (The proposals of implementation of price policy), 8. 11. 1966, submitted by Oldřich ČERNÍK, Bedřich SUCHARDA and Pavol MAJLING.

29 NA, f. 10/4, vol. 5, doc. no. 10, b. 1, Program urychlené realizace nové soustavy plánovitého řízení (Program of immediate implementation of the new planning system), 11. 3. 1966, submitted by ŠIK and TOMAN.

30 NA, f. 10/4, vol. 5, doc. no. 10, b. 1, 9. 
neur" could operate only within strictly defined borders. ${ }^{31}$ "Bureaucratic management is management bound to comply with detailed rules and regulations fixed by the authority of a superior body. The task of bureaucrat is to perform what these rules and regulation order him to do. His discretion to act according to his own best conviction is seriously restricted by them." 32 The central office had the power to determine not only the goals of society and the structure of the economy, but also make decisions regarding the allocation of resources between consumption and accumulation or concerning the placement of workforce.

The idea of what the market is about, is also far from the reality. "The structure, quality and price of products have to correspond to the situation on the market..." ${ }^{3}$ It is clear, that they have thought there is a given structure of the market and the enterprise had to "fit in". It is important to realize, that there is no given structure, but the enterprises are co-authors of the structure as well as the consumers. The structure is being formed by the actions of both sides of the market. Attempts of "fit in" without interaction are dependent on trial and error method.

Even before the price mechanism was put into practice, it was necessary to recalculate the prices due to the new system of price construction and unified payments. The assumption was to increase the price level about 19 percent. The reality was a little bit different, because the enterprises counted the payments into a new price. The increase in prices was about 30 percent. ${ }^{34}$ Acquired financial resources was supposed to be used for innovations and improving competition. Again, the reality was different. It was said, the structure of socialist economy is monopolistic by its nature so there is no motivation and pressure to improve products and the efficiency of production. That is what really happened - the enterprises used the resources for the conservation of inefficient production and consolidation of monopolistic position. While the expected average share of profit per price was $22 \%$, actually it was $78 \%$ in 1967 and about $80 \%$ in $1968 .{ }^{35}$ Although there was a possibility for the enterprises to choose a type of price (fixed, limited and flexible), the majority of prices remained in fixed regime. No one wanted to be under the pressure of the market. $87 \%$ of retail prices and over $94 \%$ of wholesale prices were still fixed. ${ }^{36}$ "Some enterprises became millionaires overnight due to recalculation of prices... The cause of problems is that the plan was based on calculation from enterprises. For most of them selfish interests were more important than interest of whole society." president Novotný commented the negative development. ${ }^{37}$ The government was forced to act. In July 1967 several regulations of wages and the use

31 První varianta tezí o postavení, úloze a řízení socialistického podniku, submitted on 22. 5. 1967, in VONDROVÁ, 2010, 141-168.

32 Ludwig von MISES, Bureaucracy, New Haven 1944, 45.

33 VONDROVÁ, 2010, 142.

34 MYANT, 1989, 144; ŠULC, 1998a, 48.

35 VONDROVÁ, 2010, 11; ŠULC, 1998a, 50.

36 NA, f. 10/4, vol. 10, doc. no. 21, b. 2, 23, Hodnocení účinnosti ekonomických nástrojů nové soustavy řízení za I. pololetí 1967 (The evaluation of the efficiency of economic instruments of new planning system in the first half of 1967), submitted by ČERNÍK, 27. 10. 1967.

37 KAPLAN, 2000, 297. 
of limited and flexible prices were adopted. Excessive profits have been confiscated. ${ }^{38}$ The political sphere was blamed for the failure of the reform which could not overcome the administrative-bureaucratic management. The heretical requirement on democratization of political system has appeared. ${ }^{39}$

\section{"Prague spring"}

The political crisis in Czechoslovakia did not have only one cause, reform, there were several reasons. The criticism of regime and requirement of democratization were growing stronger among the cultural sphere and the student movement. The national question the relations between Czechs and Slovaks also played an important role.

Despite the criticism was getting stronger and stronger, there was no doubt that socialism was the only right way. For example the reaction of the political leadership to the writers' congress was very hysterical. The only thing the writers said was that Stalinism was "ill", but it was also the heir of great humanistic movement and preserved some of the original attitudes and thoughts. The requirement was to cure the system, not to change it. ${ }^{40}$ The students just asked for better conditions on student dormitory, functional electricity and water supply. Their march through Prague in October 1967 was brutally punished by tear gas and batons. The reaction of public was very critical, but the political leadership headed by the president Novotný demanded the hard punishment for students. ${ }^{41}$ President Novotný played also the key role in the clash between Czech and Slovaks. He was very arrogant in relation to the Slovaks and did not change the "asymmetric model" of state arrangement. The requirement of creating a federation became stronger. ${ }^{42}$

The political struggle for reform, splitting the communist party into fractions and discontent inside and outside the party culminated in early 1968. In January Novotný has been revoked from party leadership, where he was replaced by Dubček. He was one of the representatives of the growing Slovak opposition. Two months later, Novotný has been also revoked from the president function. ${ }^{43}$

Due to the political changes, further implementation of economic reform was allowed to continue. In February 1968 first version of so called "Action program" was presented which

38 Usnesení vlády ČSSR č. 225 o opatřeních pro převod čtvrtého pětiletého plánu na nové ekonomické podmínky a pro vypracování plánu na rok 1968, submitted on 7. 7. 1967, in VONDROVÁ, 2010, 178-184; Usnesení vlády ČSSR č. 228 ke zprávě o základních otázkách diferenciace a regulace mezd, submitted on 7. 7. 1967, in VONDROVÁ, 2010, 184-185.

39 Galia GOLAN, Reform Rule in Czechoslovakia: The Dubček Era 1968-1969, Cambridge 1973, 23; Václav PRŮCHA, Hospodářské a sociální dějiny Československa 1918-1992 II, Brno 2009, 321; VONDROVÁ, $2010,13$.

40 IV. sjezd Svazu československých spisovatelů, Praha 27. - 29. června 1967: [protokol], Praha 1968.

41 Jaroslav PAŽOUT, „Chceme světlo“ Chceme studovat!“ Demonstrace studentů z vysokoškolských kolejí v Praze na Strahově 31. ř́jna 1967, URL: http://www.ustrcr.cz/data/pdf/pamet-dejiny/0801-4-13.pdf (visited: August 2013); ŠIK, 1990, 148.

42 KAPLAN, Kořeny československé reformy 1968 II, Brno 2002, 231-255; ŠIK, 1990, 149-151; Jan RYCHLÍK: Vznik česko-slovenské federace, in Václav KLAUS et al, Srpen 1968 - Čtyřicet let poté, Praha 2008, $123-124$.

43 PRŮCHA, 2009, 324; VONDROVÁ, 2010, 13; Jiří HOPPE, Opozice '68: sociální demokracie, KAN a K 231 v období pražského jara, Praha 2009, 20. 
became the basic document of government agenda. ${ }^{44}$ First, it was decided to increase the number of limited and flexible prices. "The second phase of the price mechanism reform will be associated... with the increasing number of the limited and flexible prices. Therefore, it is necessary to introduce strict social control of prices and effective defense of consumers' interests against monopolistic despotism of enterprises." 45 At first glance, it is clear that the requirement of increasing number of flexible or limited prices is in direct conflict with a wider price control. The only way to get the enterprises under the market pressure is to introduce real market mechanism with the private ownership of the factors of production. If there is no possibility of free entry of a new producer on the market, the current producer is not motivated to carry out efficient production and keep the prices low. If there is free access to the market, the current "monopolistic" producer is not able to arbitrarily increase the prices, because the high prices and profits would attract competition. That means, competition is not about the number of producers, but about free entry into the industry. ${ }^{46}$

Secondly, the proposal of Action program pointed out the low level of services, which was also the cause of dissatisfaction of the people concerning the socialist regime. "Communist party frankly admits, it was a mistake, when in the past all services were transferred to the socialist sector. ${ }^{\prime \prime 7}$ In the approved version of Action program it was decided to allow small personal businesses in service like repair shops, small crafts or retail sales. Unfortunately, the law regulating small personal business was not prepared. Today it is very hard to answer the question, where the borders were concerning these businesses. In other words, was there any chance to hire a workforce? Would it not be capitalistic exploitation? The way how to answer these questions can be found in Šik's theory of ownership. In his critique of private ownership, Šik argued, that the only case of the private appropriation -which does not exploit labor -is when the person is working "on himself". ${ }^{48}$ Although the proposal of allowing at least some business was a step towards better efficiency, it is clear that private entrepreneurs would soon reach a border that could not be exceeded. The successful ones would not have a chance to "grow up" into the optimal size of enterprise. Sooner or later people lose entrepreneurial motivation or there would be created inconvenient structure of the economy with fragmented small personal businesses.

Third, in the theory of the status of enterprise in the socialist economy, Action program appealed primarily to its relative independence from government authorities and responsibility of staff for the economic results. The basis of the economy was still supposed to be the plan as a scientific tool of the society for the discovery of best long-term targets. There was supposed to be also more space for small and medium-sized enterprises. ${ }^{49}$ Unlike the small personal businesses, "The proposal of law about socialist enterprises" was prepared. ${ }^{50}$ For

44 Refer to VONDROVÁ, 2010, 250-256, (First version of Action program, economic reform).

45 VONDROVÁ, 2010, 252.

46 Refer to ROTHBARD, 2009, 629-754.

47 VONDROVÁ, 2010, 253.

48 ŠIK, Ekonomika, zájmy, politika, Praha 1962, 265-266.

49 Akční program KSČ, URL: http://www.68.usd.cas.cz/files/dokumenty/edice/405_1.pdf (visited: August 2013).

50 Návrh zákona o socialistických podnicích, submitted on 21. 2. 1969, in Zdislav ŠULC, Dokumenty k hospodářské politice v Československu z let 1963 - 1969, Praha 1998b, 88-127. 
example Šulc claims that this law was supposed to be a real change in ownership relations and would solve the economic troubles of Šik's reform. ${ }^{51}$ This statement should be further examined.

\section{The proposal of law about socialist enterprises}

The proposal was divided into several parts. The first part was relatively general and dealt with the status of the enterprise and its rights. Then the other parts were dedicated to specific types of enterprises - social, public, local and also some exceptional cases.

First, in the introduction to the proposed law, according to a statement the further development of economic reform is necessary to combine with "...use of the advantages of socialist ownership, especially ownership of all people." 52 Second, also the basic definition of the enterprise did not indicate any change in ownership relations. "Socialist enterprises are legal entities established to perform entrepreneurial activities with the socially owned property. " ${ }^{33}$ Thus the proclaimed change of ownership has to be in the relation between the enterprise and the state. The law defined the state as an entity which founds and conducts entrepreneurial activities. The role of the state in starting up business is crucial and also to answer the question whether there was a change of ownership relations as Šulc claimed.

The part of law that defines the legal and property status of the enterprise clearly shows that: "The property of enterprise consists of stuff and property rights which have been entrusted to the enterprise..." but also "The socially status of the property cannot be denied . ${ }^{54}$ At first glance, it might seem that property rights were supposed to be transferred to the enterprise. But what does ownership actually mean? "Ownership is the ultimate control and direction of a resource. The owner of a property is its ultimate director, regardless of legal fictions to the contrary." 55 According to the economic concept of ownership it is evident that certainly "all the people" would not perform the property rights as the proposal claimed. As Hoppe explains: "...if all goods were co-owned by everyone, then no one, at no time and no place, would be allowed to do anything unless he had previously secured every other co-owner's consent to do so..."56 The law might highlight the ownership of "all people", but true state of affairs did not correspond legal fictions. Also at the enterprise, its director or works council could not be the owners although they might be the temporary "administrators". If the founder of the enterprise was the state which also entrusted the property to the administration, the real owner is then the state, or better - the person or the group represents it. Due to this fact, there was no change in ownership relations, the material incentives for efficient production could not occur. The reason is the difference between the real ownership and the mere administration of property rights which was in fact

\footnotetext{
51 ŠULC, $1998 b, 81$.

52 lbidem, 88.

53 lbidem, 88.

54 Ibidem, 91.
}

55 ROTHBARD, 2009, 1277.

56 Hans-Hermann HOPPE, Rothbardian Ethics,

URL: http://www.lewrockwell.com/2002/05/hans-hermann-hoppe/rothbardian-ethics (visited: August 2013). 
in the law proposal. As this fact is apparent from the document, the management of enterprise was supposed to be elected for a specific term of office. ${ }^{57}$ While the private owner (what means the permanent owner) considers in the long term, the elected "owner" (that means the administrator) is motivated to use the entrusted property as quickly as possible. "In short, government officials own the use of resources, but not their capital value. When only the current use can be owned, but not the resource itself, there will quickly ensue uneconomic exhaustion of the resources, since it will be to no one's benefit to conserve it over a period of time and to every owner's advantage to use it up as quickly as possible." ${ }^{15}$

\section{Conclusion}

Now it can be said that the military intervention in August 1968 was not the cause of the failure of Šik's reform. Despite the intervention, the theoretical discussion continued as follows from the proposal of law about socialist enterprises. Of course, it was not implemented due to "normalization" process of Czechoslovak economy, but the analysis showed, that the causes of the failure were the roots of the economy. First, the price mechanism was shown very rigid. Also the further analysis showed that without the reform of ownership relations it is impossible to use the price mechanism as a system for transmission of information. Second, the structure of planned economy was by its nature monopolistic. More autonomy concerning the enterprises just highlighted this condition. Although there were some attempts to regulate monopolistic behavior of enterprises, it was still impossible to start up the entrepreneurship freely. Only the state had the right to found an enterprise. The first realization of reform then confirmed theoretical results of the analysis. The next try of improving reformed system was not implemented. There was no political will after the military intervention. But again - the potential to change the malfunctions of the system was insignificant. It would be just other replacement of socialism towards socialism.

\section{Abstract}

The paper deals with the so-called Šik's reform in Czechoslovakia in the 1960s - its origin, implementation and consequences. After the critique of theoretical basis of the reform using the multidisciplinary approach of Austrian school, the paper formulates conclusions on the importance of this reform process. The results of the analysis are then examined in a wider context of the 1960s. The emphasis is put on the social, cultural and political development of this period. Combining the economic theory and history, the results of the thesis do not only contribute to the explanation of the consequences of the reform, but also to the theoretical debate on the implementation of socialism and its reformability.

\section{Keywords}

Socialism, Šik's reform, property rights, price mechanism, austrian school

57 ŠULC, 1998b, 93-98.

58 ROTHBARD, 2009, 1278. 